\title{
Comparative study of the soft tissue of young Japanese-Brazilian, Caucasian and Mongoloid patients
}

Thais Maria Freire Fernandes ${ }^{1}$, Arnaldo Pinzan², Renata Sathler ${ }^{3}$, Marcos Roberto de Freitas $^{4}$,

Guilherme Janson ${ }^{4}$, Fabiano Paiva Vieira ${ }^{5}$

Objective: To determine the normality mean values in the soft tissue cephalometric measurements of young Japanese-Brazilian, with normal occlusion and compare the results of the variables with compatible samples of young Caucasians and Mongoloids. Methods: Forty radiographs of young Caucasians, 32 of Japanese-Brazilians and 33 of Mongoloids were used. The three samples presented individuals with normal occlusion and well-balanced face. The samples were divided by gender due to the soft tissue characteristics and to facilitate comparison. The following statistical tests were performed: Analysis of variance (ANOVA) and analysis of covariance (ANCOVA) with $\mathrm{p}<0.05$. Results: The Japanese-Brazilian sample of females showed thinner soft tissues in the nasion region and smaller nose when compared to the Caucasians. The Mongoloid sample showed thinner tissues in the supramentonian and pogonion regions. In males, the Japanese-Brazilians had thinner tissues in the nasion region; thicker lower lip and supramentonian region in comparison to the Caucasian sample. For the Mongoloid, soft tissue was thicker in the glabella and ANS-Sn regions. Conclusion: It is necessary to use specific soft tissue standards for this mixed race.

Keywords: Ethnic groups. Reference values. Orthodontics.

Objetivo: determinar os valores médios de normalidade das grandezas cefalométricas tegumentares de jovens mestiços nipo-brasileiros com oclusão normal, e compará-los com amostras compatíveis de jovens brasileiros leucodermas e xantodermas. Métodos: foram utilizadas 40 telerradiografias de jovens leucodermas, 32 de nipo-brasileiros e 33 de xantodermas. As três amostras apresentavam indivíduos com oclusão normal e face bem balanceada. As amostras foram divididas por sexo devido às características do tecido mole e para facilitar a comparação. Foram realizados os testes estatísticos análise de variância a um critério (ANOVA) e a análise de covariância (ANCOVA) com p < 0,05. Resultados: a amostra nipo-brasileira para o sexo feminino apresentou menor espessura na região do násio e menor nariz em relação aos leucodermas. Em relação à amostra xantoderma, menor espessura na região supramentoniana e pogônio. No sexo masculino, os nipo-brasileiros apresentaram menor espessura na região do násio, maior espessura do lábio inferior e da região supramentoniana em relação à amostra leucoderma. Em relação aos xantodermas, maior espessura na região da glabela e da ENA-Sn. Conclusão: verificou-se a necessidade de se utilizar normas de tecido mole específicas para essa raça miscigenada.

Palavras-chave: Grupos étnicos. Valores de referência. Ortodontia.

${ }^{1} \mathrm{PhD}$ and Postdoc in Orthodontics, Bauru Dental School - University of São Paulo (FOB-USP).

${ }^{2}$ Associate Professor, Department of Pediatric Dentistry, Orthodontics and Public Health, Bauru Dental School, FOB-USP.

${ }^{3} \mathrm{MSc}$ in Orthodontics, USP.

${ }^{4}$ Head Professor, Department of Pediatric Dentistry, Orthodontics and Public Health, FOB-USP.

${ }^{5}$ Head Professor, Department of Pediatric Dentistry, Orthodontics and Public Health, FOB-USP.

» The author reports no commercial, proprietary or financial interest in the products or companies described in this article.
How to cite this article: Fernandes TMF, Pinzan A, Sathler R, Freitas MR, Janson G, Vieira FP. Comparative study of the soft tissue of young JapaneseBrazilian, Caucasian and Mongoloid patients. Dental Press J Orthod. 2013 MarApr;18(2):116-24.

Submitted: March 18, 2009 - Revised and accepted: August 16, 2009

» Patients displayed in this article previously approved the use of their facial and intraoral photographs.

Contact address: Thais Maria Freire Fernandes

Alameda Octávio Pinheiro Brisolla, 9-75 - Bauru/SP - Brazil

CEP: 17.012-901 -E-mail: thaismaria@hotmail.com 


\section{INTRODUCTION}

Orthodontics has the cephalometric analysis as a great diagnostic aid. Since the advent of the cephalostat, many authors have focused on establishing analyses that facilitate orthodontic planning. These studies were initially conducted in Caucasians, but it has been shown that different races have different ${ }^{12}$ cephalometric standards, thus making it necessary to establish normative values for the different racial and ethnical groups.

In multicultural societies such as Brazil, the racial differences have assumed great importance. ${ }^{12}$ The Brazilian population is presented today with a lot of intermingled people, making it necessary to recognize that the best esthetic and functional results cannot be found when using as a guide another race or ethnicity. ${ }^{22}$ Although many studies are found in the scientific literature about the soft tissue profile, there is no research on this subject comparing young Japanese-Brazilians with other races. Brazil is currently considered the country with the largest number of Japanese outside Japan and has different generations of nipponic origin, ${ }^{27}$ and a lot of miscegenation, thus it is believed that a more specific study is necessary for this ethnic group.

This study aimed to determine the normality of mean values in the soft tissue profile of young JapaneseBrazilians, with normal occlusion, as well as Brazilians and Japanese descendants comparing these results with samples of young Caucasian Brazilians and young Mongoloid Brazilians.

\section{MATERIAL AND METHODS \\ Material}

The sample consisted of 105 radiographs of young Japanese-Brazilians, Caucasians and Mongoloids, with normal occlusion and balanced face. The Japanese-Brazilian sample was selected by 3 researchers in different schools of Bauru (Brazil), and the other two samples were collected from files of the Department of Orthodontics of the Bauru Dental School - University of São Paulo. The total study sample included 40 young Caucasians (20 of each gender), 32 young Japanese-Brazilian adults (17 females and 15 males) and 33 young Mongoloid adults (17 females and 16 males). The means and standard deviations of patients' ages are shown in Table 1.

All individuals had the upper and lower permanent teeth in occlusion, with or without second and third molars; showing a balanced growth pattern; harmonic profile, satisfactory occlusion or Angle Class I malocclusion with dental casts showing a discrepancy of up to $2 \mathrm{~mm}$ in the lower anterior region. None of them went through prior orthodontic treatment.

The Caucasian group consisted of Mediterranean descendents and the Mongoloid group of individuals with Japanese ancestries. These two samples did not include individuals of mixed heritage. For the Japanese-Brazilian group, the individuals should be children or grandchildren resulting from the union of Caucasian Brazilians and Japanese (Fig 1), not including individuals from the island of Okinawa, since it was colonized by Chinese people.

\section{Methods}

Cephalometric radiographs were taken from all sample individuals in maximum intercuspation (MHI), as it is known that the differences between this mandibular position and centric relation (CR) are minimal at this age, and they minimally interfere in the cephalometric results, especially in cases of normal occlusion. ${ }^{30}$

The cephalogram tracings and measurements were made by the same researcher. The images were scanned through a flatbed Numonics, AccuGrid A30TL (Numonics Corporation, Montgomeryville, PA, USA) connected to a PC with $700 \mathrm{MHz}$ Intel $\mathrm{P} 3$ processor, to obtain the cephalometric measurements, and subsequent data transfer to the Dentofacial Planner 7.02 software (Dentofacial Planner Software Inc., Toronto, Ontario, Canada). The correction of the magnification factor due to the use of different radiographic equipment $(6 \%$ for the Caucasian sample, 9.8\% for Japanese-Brazilian, and from $7 \%$ to $8 \%$ for the Mongoloid sample) was performed by the software itself.

After obtaining the lateral cephalometric radiographs, the anatomic design and location of classic cephalometric points was performed. To determine the linear horizontal measurements, ${ }^{9,11,13}$ representing the soft tissue thickness, some measurements were made perpendicular to the N-perp line, taking the points of the soft tissue facial profile and their respective points in the dentoskeletal structures (Table 2, Fig 2).

\section{Method error}

Thirty days after the end of this stage, 20 radiographs were randomly selected and re-traced, manually and digitally, to determine result reliability. For each 
Table 1 - Number of individuals ( $\mathrm{n}$ ) in each group, the distribution by gender, sample mean age and standard deviations (SD).

\begin{tabular}{ccccc}
\hline Groups & Total & Females & Males & Mean age \\
Caucasian & 40 & 20 & 20 & 13.64 \\
Japanese-Brazilian & 32 & 17 & 15 & 13.96 \\
\hline Mongoloid & 33 & 17 & 16 & 1.28 \\
\hline
\end{tabular}
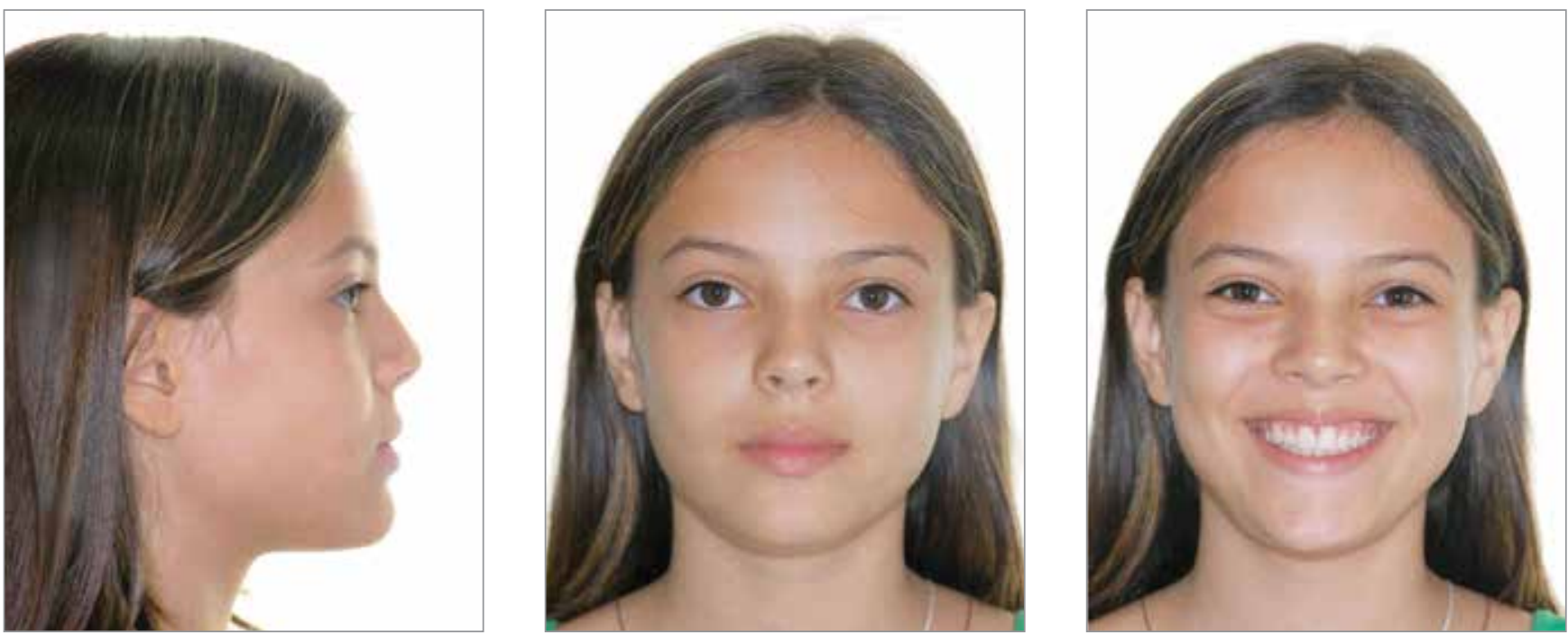

Figure 1 - Extraoral photographs of young Japanese-Brazilian female.

Table 2 - Linear horizontal measurements.

\begin{tabular}{|c|c|c|}
\hline $\mathbf{N}^{\circ}$ & Name (Abbreviation) & Definition \\
\hline 1 & $\begin{array}{l}\text { Thickness of the glabella soft tissue } \\
\text { (Gl-GL') }\end{array}$ & $\begin{array}{c}\text { Distance between the hard tissue and the soft tissue } \\
\text { glabella points }\end{array}$ \\
\hline 2 & Nasion soft tissue thickness (N-N ') & $\begin{array}{l}\text { Distance between the hard tissue and the soft tissue } \\
\text { nasion points }\end{array}$ \\
\hline 3 & Nasal thickness (Prn-Nperp) & $\begin{array}{l}\text { Distance between the pronasal point and its } \\
\text { perpendicular projection to the } \mathrm{N} \text {-perp line }\end{array}$ \\
\hline 4 & Nasal projection (Sn-Prn) & $\begin{array}{l}\text { Horizontal distance between the subnasale and } \\
\text { pronasale points }\end{array}$ \\
\hline 5 & $\begin{array}{l}\text { Thickness of the subnasale region } \\
\text { (ANS-Sn) }\end{array}$ & $\begin{array}{l}\text { Distance between the anterior nasal spine and } \\
\text { subnasale points }\end{array}$ \\
\hline 6 & $\begin{array}{l}\text { Soft tissue thickness of the anterior } \\
\text { maxillary region (A-A') }\end{array}$ & Distance between points $A$ and $A^{\prime}$ \\
\hline 7 & Upper lip thickness (ULp-UL) & $\begin{array}{l}\text { Distance between the UL point and its projection on } \\
\text { the upper incisor }{ }^{11}\end{array}$ \\
\hline 8 & Lower lip thickness (LLp-LL) & $\begin{array}{l}\text { Distance between } L L \text { point and its projection on the } \\
\qquad \text { lower incisor }^{11}\end{array}$ \\
\hline 9 & Thickness of the mentolabial sulcus (B-B') & Distance between points B and B' \\
\hline 10 & $\begin{array}{l}\text { Anterior thickness of the soft tissue } \\
\text { mentum (Pog-Pog') }\end{array}$ & $\begin{array}{c}\text { Distance between the hard tissue and the soft tissue } \\
\text { pogonion points }\end{array}$ \\
\hline
\end{tabular}

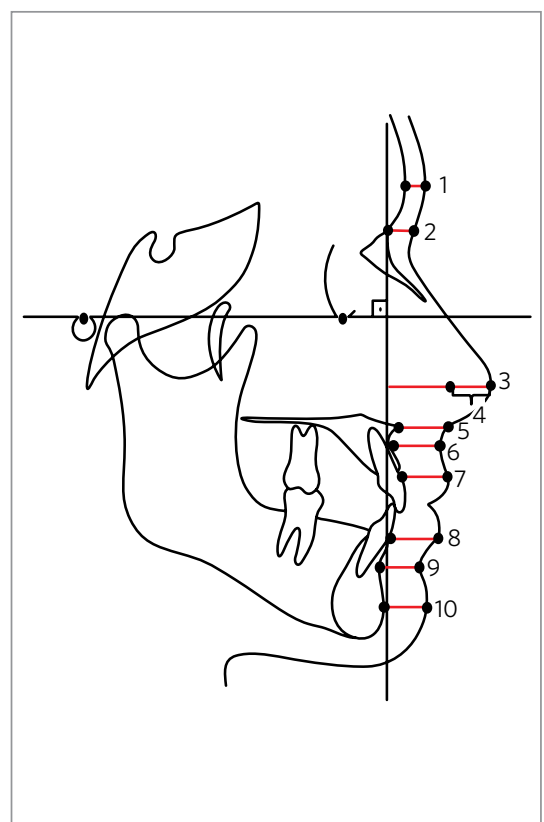

Figure 2 - Horizontal linear measurements. one of the cephalometric measurements, the systematic and random errors were evaluated, independently. The $t$ test was used to calculate the dependent systematic error at a significance level of 5\%. To estimate the random error, the formula proposed by Dahlberg $\left(\mathrm{Se}^{2}=\sum \mathrm{d}^{2} / 2 \mathrm{n}\right)$ was applied, where $\mathrm{Se}^{2}$ is the error variation, $\mathrm{d}$ is the difference between the first and second measurement and $\mathrm{n}$ is the number of double measurements. 


\section{Statistical analysis}

Descriptive statistics was used (mean and standard deviation). The Kolmogorov-Smirnov test demonstrated normal distribution for all variables allowing the use of parametric tests. Thus, for comparative statistical analysis of the data, the following parametric tests were used: ANOVA, analysis of variance with a criterion for comparison of ages, and Ancova, analysis of covariance for comparison of cephalometric variables between the samples (Caucasian, JapaneseBrazilian and Mongoloid).

Due to the lack of age compatibility in the samples, the analysis of covariance (ANCOVA) was used to verify the influence of age on the results. The analysis of covariance aims to assess the effect of one or more explanatory factors rated in nature (in this research, the race) in a given variable, excluding the influence of possible quantitative factors (in this case, the age) that may influence the variables. The results were considered statistically significant for $\mathrm{p}<0.05$. The tests were performed using the Statistica software for Windows 6.0 (Statistica for Windows 6.0, Copyright StatSoft, Inc. Tulsa, USA).

\section{RESULTS}

The systematic and random errors are shown in Table 3. Only two variables showed a systematic error and for the random error all variables showed acceptable values of less than $1 \mathrm{~mm}$ (Table 3 ). There were significant differences regarding age for both genders (Table 4) and for this reason the analysis of covariance was performed (Tables 5 and 6).

Table 3 - Evaluation of systematic and random errors by dependent $t$ test and Dahlberg's formula.

\begin{tabular}{|c|c|c|c|c|c|c|}
\hline \multirow{2}{*}{ Variable } & \multicolumn{2}{|c|}{$1^{\text {st }}$ tracing } & \multicolumn{2}{|c|}{$2^{\text {nd }}$ tracing } & \multirow{2}{*}{$\mathbf{p}$} & \multirow{2}{*}{ Dahlberg } \\
\hline & Mean & SD & Mean & SD & & \\
\hline \multicolumn{7}{|c|}{ Soft tissue thickness ( $\mathrm{mm}$ ) } \\
\hline \multicolumn{7}{|l|}{ Upper face } \\
\hline Gl-GL' & 5.93 & 0.96 & 5.90 & 0.93 & 0.746 & 0.31 \\
\hline $\mathrm{N}-\mathrm{N}^{\prime}$ & 5.56 & 1.47 & 5.38 & 1.40 & 0.273 & 0.43 \\
\hline \multicolumn{7}{|l|}{ Midface } \\
\hline Prn-Nperp & 26.98 & 2.64 & 26.86 & 2.57 & 0.729 & 0.97 \\
\hline Sn-Prn & 12.05 & 1.37 & 12.11 & 1.38 & 0.245 & 0.32 \\
\hline ANS-Sn & 10.31 & 3.51 & 9.95 & 2.98 & 0.384 & 0.96 \\
\hline \multicolumn{7}{|l|}{ Lower face } \\
\hline$A-A^{\prime}$ & 13.98 & 2.88 & 14.97 & 2.88 & 0.098 & 0.89 \\
\hline ULp-UL & 14.39 & 2.21 & 13.78 & 1.98 & $0.032^{\star}$ & 0.84 \\
\hline LLp-LL & 14.66 & 1.72 & 14.23 & 1.57 & $0.039^{\star}$ & 0.62 \\
\hline$B-B^{\prime}$ & 12.17 & 1.59 & 12.35 & 1.61 & 0.294 & 0.45 \\
\hline Pog-Pog' & 11.71 & 1.41 & 11.69 & 1.37 & 0.946 & 0.47 \\
\hline
\end{tabular}

* Statistically significant at $p<0.05$.

Table 4 - Comparison of mean ages between the different races, in males and females included in the samples, by analysis of variance (ANOVA).

\begin{tabular}{|c|c|c|c|c|c|c|c|c|c|c|}
\hline \multirow{2}{*}{ Gender } & \multicolumn{3}{|c|}{ Caucasian } & \multicolumn{3}{|c|}{ Japanese-Brazilian } & \multicolumn{3}{|c|}{ Mongoloid } & \multirow{2}{*}{$\mathbf{p}$} \\
\hline & $n$ & Mean & SD & $n$ & Mean & SD & n & Mean & SD & \\
\hline Female & 20 & $13.70^{\mathrm{a}}$ & 0.87 & 17 & $13.22^{\mathrm{a}}$ & 1.04 & 17 & $15.65^{b}$ & 2.44 & $0.000^{*}$ \\
\hline Male & 20 & $13.57^{\mathrm{a}}$ & 1.03 & 15 & $14.79^{a \cdot b}$ & 1.01 & 16 & $15.56^{b}$ & 2.51 & $0.002^{*}$ \\
\hline Total & 40 & $13.63^{a}$ & 0.97 & 32 & $13.96^{\mathrm{a}}$ & 1.29 & 33 & $15.61^{b}$ & 2.44 & $0.000 *$ \\
\hline
\end{tabular}

* Statistically significant at $p<0.05$

Different letters show significant differences between means by Tukey test. 
Table 5 - Comparison of variables between the female samples (ANCOVA and Tukey's test).

\begin{tabular}{|c|c|c|c|c|c|c|c|c|}
\hline \multirow{2}{*}{ Variable } & \multicolumn{2}{|c|}{ Caucasian $(n=20)$} & \multicolumn{2}{|c|}{ Japanese-Brazilian $(n=17)$} & \multicolumn{2}{|c|}{ Mongoloid ( $n=17)$} & \multirow{2}{*}{ p Age } & \multirow{2}{*}{$\mathbf{p}$} \\
\hline & Mean & SD & Mean & SD & Mean & SD & & \\
\hline \multicolumn{9}{|c|}{ Soft tissue thickness (mm) } \\
\hline \multicolumn{9}{|l|}{ Upper face } \\
\hline $\mathrm{Gl}-\mathrm{GL}^{\prime}$ & 5.87 & 0.49 & 6.01 & 0.68 & 5.94 & 0.87 & 0.196 & 0.652 \\
\hline $\mathrm{N}-\mathrm{N}^{\prime}$ & $7.01^{a}$ & 0.88 & $6.14^{b}$ & 1.19 & $5.87^{b}$ & 1.01 & 0.744 & $0.005^{\star}$ \\
\hline \multicolumn{9}{|l|}{ Midface } \\
\hline Prn-Nperp & $28.83^{a}$ & 3.75 & $26.35^{a . b}$ & 2.52 & $24.90^{b}$ & 3.29 & 0.939 & $0.005^{*}$ \\
\hline Sn-Prn & $14.52^{\mathrm{a}}$ & 1.45 & $12.01^{\mathrm{b}}$ & 1.48 & $11.73^{b}$ & 1.66 & 0.128 & $0.000 *$ \\
\hline ANS-Sn & 10.07 & 1.93 & 9.64 & 1.48 & 8.84 & 1.96 & 0.504 & 0.115 \\
\hline \multicolumn{9}{|l|}{ Lower face } \\
\hline$A-A^{\prime}$ & $14.38^{a}$ & 1.92 & $13.10^{a . b}$ & 1.58 & $12.65^{b}$ & 1.45 & 0.941 & $0.010^{*}$ \\
\hline ULp-UL & 12.80 & 1.35 & 13.50 & 1.85 & 12.66 & 1.86 & 1.000 & 0.386 \\
\hline LLp-LL & 13.82 & 1.09 & 13.79 & 1.19 & 14.11 & 1.63 & 0.555 & 0.944 \\
\hline B-B' & $11.23^{a}$ & 1.49 & $10.71^{a}$ & 0.63 & $13.02^{b}$ & 1.84 & 0.475 & $0.002^{*}$ \\
\hline Pog-Pog' & $11.47^{\mathrm{a}}$ & 1.26 & $11.22^{\mathrm{a}}$ & 1.36 & $12.25^{b}$ & 2.20 & $0.002^{*}$ & $0.003^{*}$ \\
\hline
\end{tabular}

Different letters show significant differences between means by Tukey test

* Statistically significant at $p<0.05$

Table 6 - Comparison of variables between the male samples (ANCOVA and Tukey's test).

\begin{tabular}{|c|c|c|c|c|c|c|c|c|}
\hline \multirow{2}{*}{ Variable } & \multicolumn{2}{|c|}{ Caucasian $(n=20)$} & \multicolumn{2}{|c|}{ Japanese-Brazilian $(n=15)$} & \multicolumn{2}{|c|}{ Mongoloid $(n=16)$} & \multirow{2}{*}{ p Age } & \multirow{2}{*}{$\mathbf{p}$} \\
\hline & Mean & SD & Mean & SD & Mean & SD & & \\
\hline \multicolumn{9}{|c|}{ Soft tissue thickness (mm) } \\
\hline \multicolumn{9}{|l|}{ Upper face } \\
\hline Gl-GL' & $5.91^{a . b}$ & 1.04 & $6.54^{\mathrm{a}}$ & 0.81 & $5.69^{b}$ & 0.65 & 0.478 & $0.026^{*}$ \\
\hline $\mathrm{N}-\mathrm{N}^{\prime}$ & $7.93^{a}$ & 1.00 & $6.56^{b}$ & 1.09 & $6.08^{b}$ & 1.12 & 0.455 & $0.000^{*}$ \\
\hline \multicolumn{9}{|l|}{ Midface } \\
\hline Prn-Nperp & 28.50 & 3.38 & 29.56 & 3.18 & 26.72 & 3.13 & 0.304 & 0.090 \\
\hline Sn-Prn & 13.02 & 2.44 & 13.43 & 2.05 & 13.32 & 1.54 & 0.432 & 0.938 \\
\hline ANS-Sn & $11.37^{a}$ & 2.27 & $11.17^{\mathrm{a}}$ & 2.26 & $9.52^{b}$ & 2.21 & 0.369 & $0.033^{*}$ \\
\hline \multicolumn{9}{|l|}{ Lower face } \\
\hline$A-A^{\prime}$ & 15.60 & 1.95 & 15.76 & 2.02 & 14.58 & 1.49 & 0.936 & 0.268 \\
\hline ULp-UL & 14.24 & 1.78 & 15.06 & 1.66 & 14.17 & 2.34 & 0.071 & 0.298 \\
\hline LLp-LL & $14.88^{a}$ & 1.21 & $16.60^{b}$ & 1.74 & $16.77^{b}$ & 2.17 & 0.745 & $0.008^{*}$ \\
\hline $\mathrm{B}^{-\mathrm{B}^{\prime}}$ & $11.23^{a}$ & 1.07 & $12.68^{b}$ & 1.30 & $13.68^{b}$ & 1.49 & 0.142 & $0.000 *$ \\
\hline Pog-Pog' & 12.18 & 1.69 & 12.95 & 1.49 & 12.64 & 2.14 & 0.277 & 0.252 \\
\hline
\end{tabular}

Different letters show significant differences between means by Tukey test

* Statistically significant at $p<0.05$

\section{DISCUSSION}

The same appearance is not always appropriate for all races and ethnic groups, however, normative studies of cephalometric variables are important for precisely determining the variations of what is normal. ${ }^{22}$ There are some studies about soft tissue in Caucasians and Mongoloids, but no specific study about JapaneseBrazilians and the comparison of these three groups.
Besides, it is difficult to compare cephalometric studies in different races due to sample characteristics, statistical methods, geographic distribution and racial definitions. The groups that were used in this study met the same inclusion criteria, especially regarding race, which was strictly evaluated.

Some studies explained that when analyzing the soft tissue profile, it is necessary to differentiate the 
variables for men and women. ${ }^{4,17}$ The subdivision by gender and racial group has received support in other studies, ${ }^{14,22}$ that emphasized that the accurate use of cephalometrics, should consider these aspects. In this study, the genders were analyzed separately for better comparison of soft tissue profile.

Thickness alterations on the soft tissue profile vary with age and gender. ${ }^{29}$ Besides this fact, the dento-skeletal changes can directly influence the desired esthetics. The soft tissue may also vary in thickness, length and position, which makes the study of the outline of these tissues necessary, in order to achieve a total facial harmony. ${ }^{8}$ According to Arnett et $\mathrm{al},{ }^{4}$ the thickness measurements of the upper lip, lower lip, point B region, pogonion, and chin alter the facial profile. As well as the variation of lip thickness, especially during retraction or dental protraction. ${ }^{8}$ Differences found in the soft tissue profile in this study can be seen in the pictures of the mean profile of the three samples (Figs $3 \mathrm{~A}$ and B).

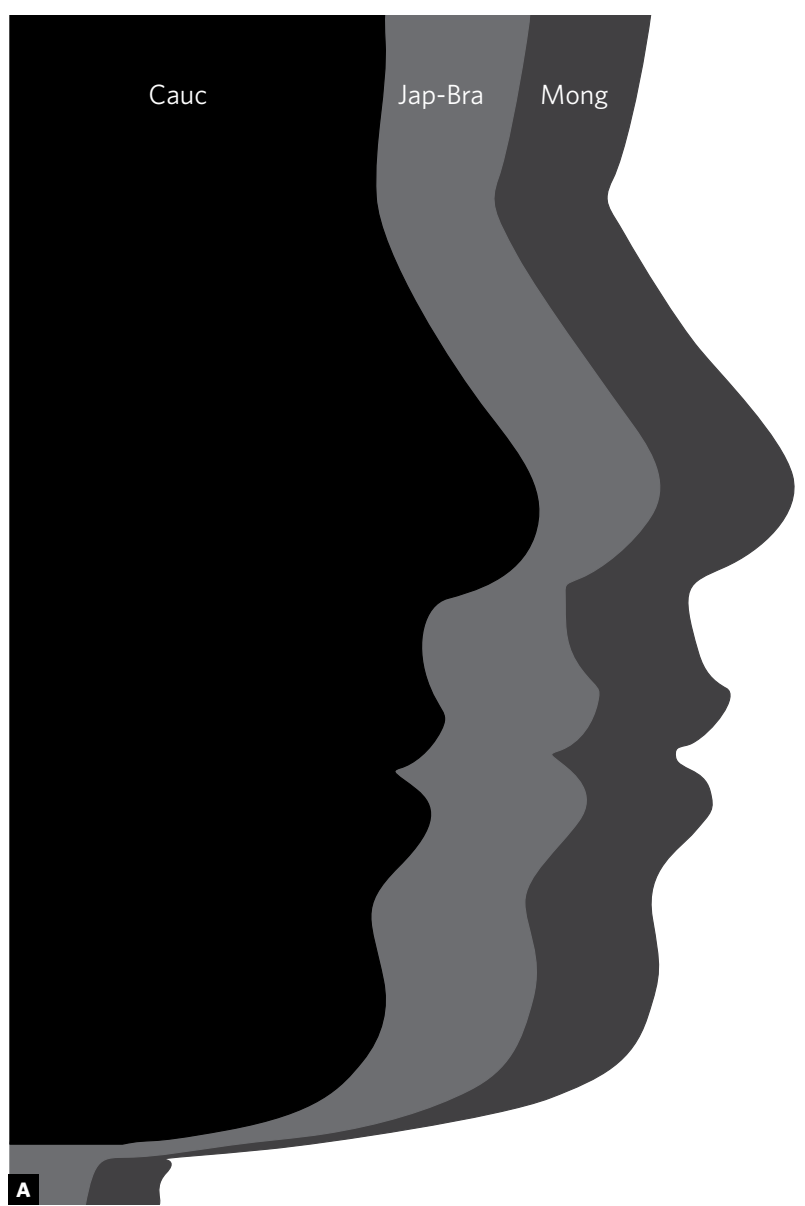

Only the variables that showed statistically significant difference after comparison with a sample of Caucasian and Mongoloid, will be discussed (Tables 5 and 6 ). These magnitudes were grouped according to their representation and to facilitate the understanding, divided into upper, middle and lower face. The results are discussed focusing on the JapaneseBrazilian sample and their differences to the Mongoloid and Caucasian samples.

\section{Upper face}

Considering the upper face a difference was observed in the thinnest region of the nasion $\left(\mathrm{N}-\mathrm{N}^{\prime}\right)$ for the Mongoloid (female $5.87 \mathrm{~mm}$, female 6.08) and Japanese-Brazilian groups (female $6.14 \mathrm{~mm}, 6$ male, $56 \mathrm{~mm}$ ) when compared to the Caucasian sample (female $7.01 \mathrm{~mm}, 7.93 \mathrm{~mm}$ female). This may be related to the fact that the soft tissues of the Japanese individuals in these regions are more firmly attached and have

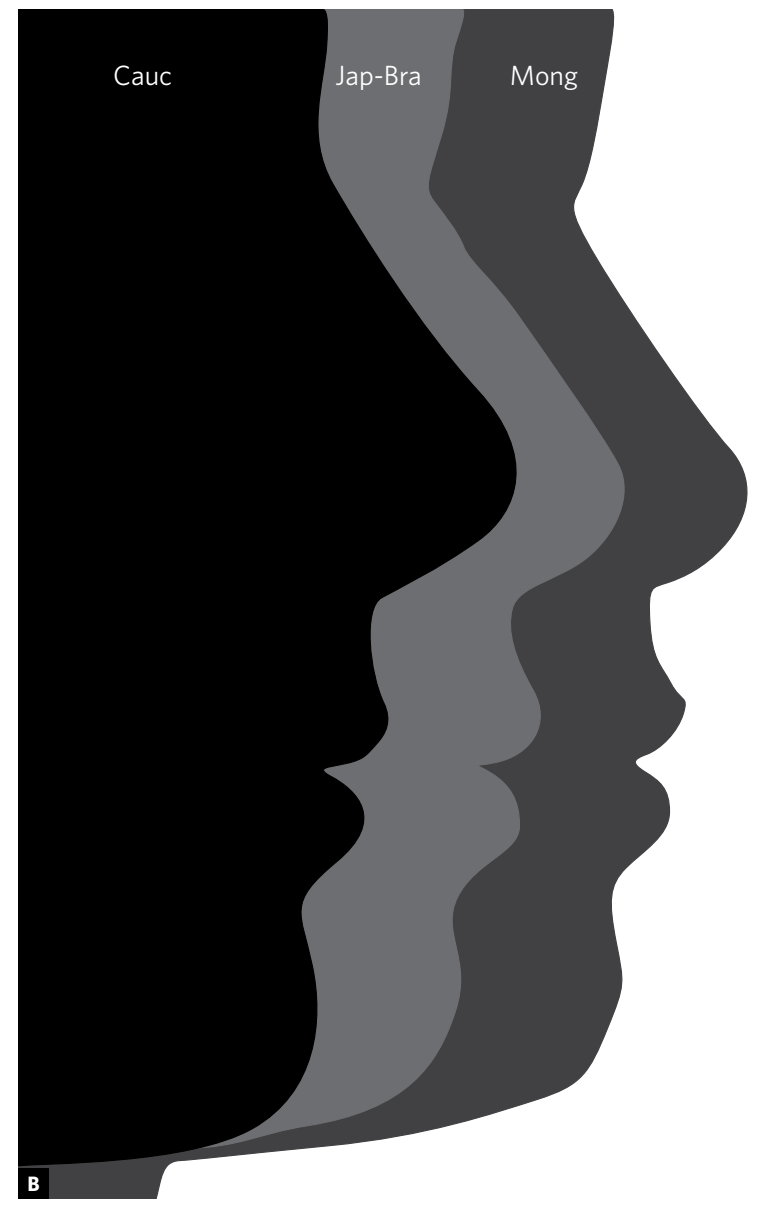

Figure 3 - Illustrative comparison of the profile means between Caucasian, Japanese-Brazilian and Mongoloid groups: (A) female, (B) male. 
more subtle growth when compared to the Caucasian sample. ${ }^{29}$ The expectation that Japanese descendents have a flatter area in the region of the nasion and this appearance can be associated to a thinner soft tissue is, therefore, confirmed.

Also regarding the upper face, males of the Japanese-Brazilian sample showed statistically higher values of soft tissue thickness $(6.54 \mathrm{~mm})$ in the glabella region (Gl-Gl') when compared to the Mongoloid sample $(5.69 \mathrm{~mm})$. This increased thickness emphasizes even more the flattening found for Japanese-Brazilians in the region of nasion (N-N'). This variable quantifies the thickness in the nasion region and presented particular characteristics regarding the ethnicity for both genders. In most cases, the thickness in the nasion region is greater in men than in women and in both genders, the thickness of this area tends to remain constant or decrease slightly with age..$^{25,29}$

Although the upper face area is not an area of direct action for the orthodontist and it will not be changed with orthodontic treatment itself, the practitioner must be aware of the general profile aspect.

\section{Midface}

As for the thickness of soft tissues in this region in females, it was observed that the Japanese-Brazilian sample showed intermediate values for variables SnPrn and Prn-Nperp. When compared to Caucasians $(14.52 \mathrm{~mm})$, statistically lower values for the size of the nose (Prn-Sn) were found in the Japanese-Brazilian sample $(12.01 \mathrm{~mm})$ and Mongoloids $(11.73 \mathrm{~mm})$, which can be confirmed by previous findings that Asians have smaller noses when compared to other populations. ${ }^{1}$ Corroborating with these findings, the smallest nose size was also evidenced by the variable Prn-Nperp in the Mongoloid sample $(24.90 \mathrm{~mm})$ when compared to Caucasians $(28.83 \mathrm{~mm})$.

The only variable for males that showed a significant difference in this region of the face was the ANS-Sn which showed intermediate values for Japanese-Brazilians $(11.17 \mathrm{~mm})$ but similar to the values found for the Caucasians $(11.37 \mathrm{~mm})$. This variable is also related to the nose and confirmed the trend of Mongoloids having smaller noses $(9.52 \mathrm{~mm})$ when compared to other races. ${ }^{1,24}$ As the amount of increase in nasal projection (Prn-Nperp and Sn-Prn) in boys occurs in older ages, ${ }^{6,8}$ it is speculated that this is the reason for the lack of dif- ference for this gender in this research, since Japanese individuals, even older, show a smaller nose $(26.72 \mathrm{~mm})$ when compared to other samples.

Angle, in his book published in 1907, stated that the amount of nose development may influence the final treatment result, and correction of isolated dental disharmonies can often detract the profile. ${ }^{13}$ Thus, the nose size is a factor that should be evaluated in terms of treatment ${ }^{25}$ because irreversible procedures such as extractions and retractions may affect facial profile esthetics.

\section{Lower face}

The lower face is the actual area of orthodontic action and this requires strict evaluation, which justifies the fact that most of the variables in this study are related to this region.

\section{Subspinale region ( $\left.A-A^{\prime}\right)$}

The thickness of the subspinale region (A-A') directly affects the shape of the soft tissue profile and only females showed significant differences between the races. The Caucasian sample showed the highest value $(14.38 \mathrm{~mm})$ and it is known that the increased thickness of soft tissues in this region, may mask a dental protrusion. ${ }^{9}$ In this Japanese-Brazilian sample, the thickness was numerically intermediate $(13.10 \mathrm{~mm})$ and the lowest value was found in the Mongoloid sample $(12.65 \mathrm{~mm})$ which, associated to the small nose in this group, may evidence even more a lip protrusion in Japanese descendents.

According to Subtelny ${ }^{25}$ the thickness of this region grows on average $5 \mathrm{~mm}$, from 3 to 18 years old, and comparatively, there is more soft tissue covering point A region then there is covering the nasion and pogonion regions. This was also found in this study for all samples, in both genders. Thus, the soft profile tends to change more in the direction of increased thickness than in the reduction of facial convexity. This may partly explain why the soft tissue, without the inclusion of the nose, tends to get progressively less convex over the age, as occurs in the skeletal profile. ${ }^{25}$

\section{Lower lip (LLP-LL)}

Assessing the region of the lower face in males (Table 6), attention is drawn to the thickness of the lower lip (LLp-LL), which was higher in Japanese-Brazilians $(16.60 \mathrm{~mm})$ and Mongoloids $(16.77 \mathrm{~mm})$. This thick- 
ness probably also contributes to the appearance of a more convex profile in the Asian descents. ${ }^{28}$ The increased thickness of the lower lip can mask a Class II relation and promote a more straight profile, bringing at least esthetic benefits to Asian descendants with malocclusions such as these.

Over the years, the lips suffer a redirection that causes a wilted appearance. The decrease in thickness is compensated with a proportional increase in height of the lips, allowing the volume to remain the same. ${ }^{15}$ Based on this, fact, orthodontic planning can be established more thoroughly in young patients with gingival smile, considering these changes during growth.

The thickness, height and position of the lips, particular characteristics of the individuals, can influence the response of the soft tissue to retraction movement. Patients with thicker lips respond differently to orthodontic treatment than patients with thinner lips. ${ }^{20}$ Patients with thinner lips have a higher correlation between changes in hard tissue and these changes' reflect in the soft tissue. It is important to note that orthodontists should be aware of the thickness of the lips in the treatment plan, not to overestimate the changes that may occur in soft tissue.

\section{Supramentonian region ( $\left.B-B^{\prime}\right)$ and pogonion (Pog-Pog')}

Japanese-Brazilian girls had less thickness in the supramentonian region $(10.71 \mathrm{~mm})$ and the Mongoloid sample had more thickness $(13.02 \mathrm{~mm})$ in this region. In this aspect, the girls had similar characteristics to the Caucasians. Unlike males, the supramentonian region (B-B') showed greater thickness in JapaneseBrazilians $(12.68 \mathrm{~mm})$ and Mongoloids $(13.68 \mathrm{~mm})$, which contributes to a straighter mentolabial sulcus. For these races, the greater thickness of the lower lip and mentolabial sulcus features, emphasize the care that the orthodontist should have with relapses, since it is known that muscle behavior, depending on the intensity, has a greater chance of recurrence ${ }^{7}$ and more stretched muscles tend to act even more.

The pogonion region for girls was statistically significant, both for the race factor as for the age factor, suggesting the need for attention to this variable, because the difference occurs even for the same ages. A smaller thickness of this region for the JapaneseBrazilians (11.22 $\mathrm{mm}$ ) and greater for the Mongoloid sample $(12.25 \mathrm{~mm})$ was found, which is also the sample of older people. Thus, the greater thickness of this area, may be related to higher mean age of Japanese women (15.65 years), since the tendency is that the pogonion thickness increases with age, when evaluating only the thickness itself. ${ }^{5,21}$

The previous aspects clearly show that soft tissues do not form a layer of uniform thickness that simply molds to the configuration of the underlying dentoskeletal structures. Therefore, it must be considered that individual variability on the thickness of soft tissues may reflect greatly on facial profile harmony, making the evaluation of this factor necessary during the diagnosis and planning of orthodontic treatment. ${ }^{8}$

\section{FINAL CONSIDERATIONS}

When performing comparisons such as the one performed in this study, it is emphasized that people should not be obsessed with numbers, but should observe the characteristics of each person. It is known that the period and environment in which people live has a direct influence on the concept of beauty. Alcalde et $\mathrm{al}^{2}$ reported that Japanese living in Japan, have different expectations regarding the treatment of those living in other regions of the world, due to their social differences and cultural influences. Still, Miyajima et $\mathrm{al}^{19}$ reported the revival of a sense of ethnic pride, especially in big cities. Besides, patient demands have increased in the search of an exclusive orthodontic treatment, which is based on standards derived from their race or specific ethnic group. ${ }^{16}$

Given the anthropological differences of facial and dental standards, Miura, Inoue and Suzuki ${ }^{18}$ concluded that, besides having different values, the treatment target for the Japanese should also be different from the Caucasian. Although respecting the patient's expectations, it is important to make them aware of the effects that certain changes may bring. Many times, what is normal for a race may not be so for another race, and this has to be considered. In clinical terms, it is known that besides the labial biprotrusion, it is normal for the Asian descendants to show dental double protrusion ${ }^{1,16,23,26}$ Thus, a combination of different individualized brackets prescriptions ${ }^{10}$ could allow a satisfactory final result for this race, because the requirements for Class II malocclusion cases have more buccal torque for the lower incisors and those 
used for Class III malocclusion have greater buccal torque for the upper incisors. ${ }^{10}$

Recognizing that racial influences and characteristics have an important role in guiding the goals of orthodontic treatment and their esthetic results is critical to understand the value and necessity of individualized orthodontic treatment and the study of specific standards for each ethnic group. Thus, common sense should prevail, since it is often not possible to achieve the "ideal standard". The amount of tooth movement, tissue damage and increased risk of recurrence may contraindicate an action that seeks only the rigorous esthetic imposed by social environment. It is necessary to safeguard the conditions of muscle balance and notice what is acceptable for each individual.

\section{CONCLUSION}

Based on the methodology and results of this research, it can be concluded that the mixed race sample of Japanese-Brazilians has its own characteristics, such as:

" Females:

- Reduced thickness in the nasion and lower nose regions in relation to Caucasians.

- Reduced thickness in the supramentonian and pogonion regions compared to Mongoloids.

Males:

- Reduced thickness in the nasion region, greater thickness of the lower lip and the supramentonian regions in relation to Caucasians.

- Greater thickness in the glabella and the ANS-Sn regions compared to Mongoloids.
1. Alcalde RE, Jinno T, Orsini MG, Sasaki A, Sugiyama RM, Matsumura T. Soft tissue cephalometric norms in Japanese adults. Am J Orthod Dentofacial Orthop. 2000;118(1):84-9.

2. Alcalde RE, Jinno T, Pogrel MA, Matsumura T. Cephalometric norms in Japanese adults. J Oral Maxillofac Surg. 1998:56(2):129-34.

3. Angle EH. Treatment of malocclusion of the teeth. Angle's system. Phipadelphia Angle; 1907.

4. Arnett GW, Jelic JS, Kim J, Cummings DR, Beress A, Worley CM Jr, et al. Soft tissue cephalometric analysis: diagnosis and treatment planning of dentofacial deformity. Am J Orthod Dentofacial Orthop. 1999:116(3):239-53.

5. Behrents RG. An atlas of growth in the aging craniofacial skeleton [monograph]. Arbor: Center for Human Growth and Development; 1985.

6. Bishara SE, Hession TJ, Peterson LC. Longitudinal soft-tissue profile changes: a study of three analyses. Am J Orthod. 1985;88(3):209-23.

7. Brock RA 2nd, Taylor RW, Buschang PH, Behrents RG. Ethnic differences in upper lip response to incisor retraction. Am J Orthod Dentofacial Orthop 2005;127(6):683-91; quiz 755.

8. Burstone CJ. The integumental profile. Am J Orthod Dentofacial Orthop 1958:44(1):1-25

9. Burstone CJ. Integumental contour and extension patterns. Angle Orthod. 1959;29(2):93-104.

10. Capelozza Filho L, Silva Filho O, Ozawa TE, Cavassan A. Individualização de braquetes na técnica de straight-wire: revisão de conceitos e sugestão de indicações para uso. Rev Dental Press Ortod Ortop Facial. 1999:4(4):87-106.

11. Dainesi EA. A influência dos padrões extremos de crescimento da face sobre o perfil tegumentar, analisada cefalometricamente em jovens leucodermas brasileiros [tese]. Bauru (SP): Universidade de São Paulo; 1998.

12. Freitas LM, Pinzan A, Janson G, Freitas KM, Freitas MR, Henriques JF. Facial height comparison in young white and black Brazilian subjects with normal occlusion. Am J Orthod Dentofacial Orthop. 2007:131(6):706.e1-6.

13. Holdaway RA. A soft-tissue cephalometric analysis and its use in orthodontic treatment planning. Part I. Am J Orthod. 1983;84(1):1-28.

14. Huang WJ, Taylor RW, Dasanayake AP. Determining cephalometric norms for Caucasians and African Americans in Birmingham. Angle Orthod. 1998;68(6):503-11; discussion 512.

15. Iblher N. Changes in the aging upper lip - a photomorphometric and MRI-based study (on a quest to find the right rejuvenation approach). J Plast Reconstr Aesthet Surg. 2008:61(10):1170-6.

16. loi H, Nakata S, Nakasima A, Counts A. Effect of facial convexity on anteroposterior lip positions of the most favored Japanese facial profiles. Angle Orthod. 2005;75(3):326-32.
17. Kalha AS, Latif A, Govardhan SN. Soft-tissue cephalometric norms in a South Indian ethnic population. Am J Orthod Dentofacial Orthop. 2008;133(6):876-81

18. Miura F, Inoue N, Suzuki K. Cephalometric standards for Japanese according to the Steiner analysis. Am J Orthod. 1965;51:288-95

19. Miyajima K, McNamara JA Jr, Kimura T, Murata S, lizuka T. Craniofacial structure of Japanese and European-American adults with normal occlusions and wellbalanced faces. Am J Orthod Dentofacial Orthop. 1996;110(4):431-8.

20. Oliver BM. The influence of lip thickness and strain on upper lip response to incisor retraction. Am J Orthod. 1982;82(2):141-9.

21. Pecora NG, Baccetti T, McNamara JA Jr. The aging craniofacial complex: longitudinal cephalometric study from late adolescence to late adulthood. Am J Orthod Dentofacial Orthop. 2008;134(4):496-505.

22. Pinzan A. "Upgrade" nos conceitos da interpretação das medidas cefalométricas. In: Sakai E, Cotrim-Ferreira FA, Martins NS. Nova visão em ortodontia, ortopedia funcional dos maxilares. São Paulo: Ed. Santos; 2006. p. 41-9.

23. Sathler RC. Estudo comparativo do padrão cefalométrico de jovens mestiços nipo-brasileiros: grandezas dentárias e esqueléticas [dissertação]. Bauru (SP): Universidade de São Paulo; 2009

24. Scavone H Jr, Trevisan H Jr, Garib DG, Ferreira FV. Facial profile evaluation in Japanese-Brazilian adults with normal occlusions and well-balanced faces. Am J Orthod Dentofacial Orthop. 2006;129(6):721.e1-5

25. Subtelny JD. A longitudinal study of soft-tissue facial structures and their profile characteristics defined in relation to underlying skeletal structures. Am J Orthod Dentofacial Orthop. 1959:45(7):481-507.

26. Takahashi R. Padrão cefalométrico FOB-USP para jovens nipo-brasileiros com oclusão normal [dissertação]. Bauru (SP): Universidade de São Paulo; 1998.

27. Tomita NE, Chinellato LEM, Franco LJ, lunes M, Freitas JAS, Lopes ES. Condições de saúde bucal e diabetes mellitus na população nipo-brasileira de Bauru-SP. J Appl Oral Sci. 2003:11(1):15-20.

28. Utsuno H, Kageyama T, Deguchi T, Umemura Y, Yoshino M, Nakamura H, et al. Facial soft tissue thickness in skeletal type I Japanese children. Forensic Sci Int. 2007:172(2-3):137-43

29. Utsuno H, Kageyama T, Uchida K, Yoshino M, Miyazawa H, Inoue K. Facial soft tissue thickness in Japanese female children. Forensic Sci Int. 2010;199(1-3):109.e1-6

30. Williamson EH, Caves SA, Edenfield RJ, Morse PK. Cephalometric analysis: comparisons between maximum intercuspation and centric relation. Am J Orthod. 1978;74(6):672-7. 